\title{
Blood Donor Screening for Hepatitis E Virus in the European Union
}

\author{
Fiona Boland $^{\mathrm{a}} \quad$ Auxiliadora Martinez $^{\mathrm{a}}$ Louise Pomeroy ${ }^{\mathrm{a}}$ Niamh O'Flaherty ${ }^{\mathrm{a}}$ b \\ a rrish Blood Transfusion Service (IBTS), NAT Laboratory, Dublin, Ireland; \\ ${ }^{b}$ National Virus Reference Laboratory, University College Dublin (UCD), Dublin, Ireland
}

\section{Keywords}

Hepatitis E virus · Nucleic acid testing · Viral load .

European Union

\begin{abstract}
This review article summarises hepatitis E virus (HEV) blood donation screening strategies in effect in the European Union (EU). Since 2012, eight EU countries have implemented HEV screening. Local rates of seroprevalence, RNA incidence, and molecular epidemiology are variable and not usually directly comparable. We report a range of HEV-RNA reactivity rates from 1 in 744 donations (France) to 1 in 8,636 donations (Wales) with an overall EU rate of 1 in 3,109 donations (3.2 million donations screened). HEV genotypes 3c, $3 \mathrm{e}$, and $3 \mathrm{f}$ are the most frequently reported subtypes. In these 8 countries, both universal $(n=5)$ and selective $(n=3)$ screening policies have been introduced utilising either individual donation (ID; $n=1$ ) or mini-pool (MP; $n=7$; MP-6, $-16,-24$, and -96) testing. We also describe the Irish experience of HEV screening utilising an ID-NAT-based donor screening algorithm which intercepts donations even from those with low-level viraemia; 21 of 56 donors (37.5\%) had a viral load $(\mathrm{VL})<100 \mathrm{IU} / \mathrm{mL}$. We performed a MP-24 experiment which may prove useful to colleagues in relation to donor screening and associated blood component transmissibility. Irish results indicate that $59 \%$ of donors with a $\mathrm{HEV}-\mathrm{VL}<450 \mathrm{IU} / \mathrm{mL}$ may have screened negative in a MP-24.
\end{abstract}

(c) 2019 S. Karger AG, Basel

\section{Introduction}

Many blood establishments have assessed the need to supply hepatitis E virus (HEV) RNA tested blood components to mitigate the risk of transfusion transmitted (TT)$\mathrm{HEV}$. This is despite the knowledge that dietary exposure to HEV exceeds the risk of blood transfusion in the majority of cases $[1,2]$. In the absence of blood donor screening regulation to drive a standard European Union (EU) approach, decisions by blood services in relation to $\mathrm{HEV}$ are guided by logistic, economic, and ethical complexities. From January 1, 2015, the European Pharmacopoeia set a mandatory requirement for HEV-NAT screening of solvent/detergent (S/D)-treated plasma [3]. In 2017, the European Centre for Disease Prevention and Control (ECDC) published a surveillance report [4] encompassing 10 years of epidemiological data on HEV in Europe. During this time frame, $80 \%$ of $\mathrm{HEV}$ infections $(16,810 / 21,018)$ were reported in 3 EU countries: Germany, France, and the UK. Another 2017 publication which followed an ECDC expert consultation meeting assessing the risk and prevention of HEV transmission through substances of human origin (Lisbon, May 27, 2016; participants from 11 EU countries) commented: "if implemented, the screening of blood donations should go hand in hand with raising clinicians' awareness and strict dietary recommendation for patients at risk" [5]. A consultation survey on HEV screening involving 16 different countries suggested that "blood screening is an option but

\section{KARGER}

(C) 2019 S. Karger AG, Basel 


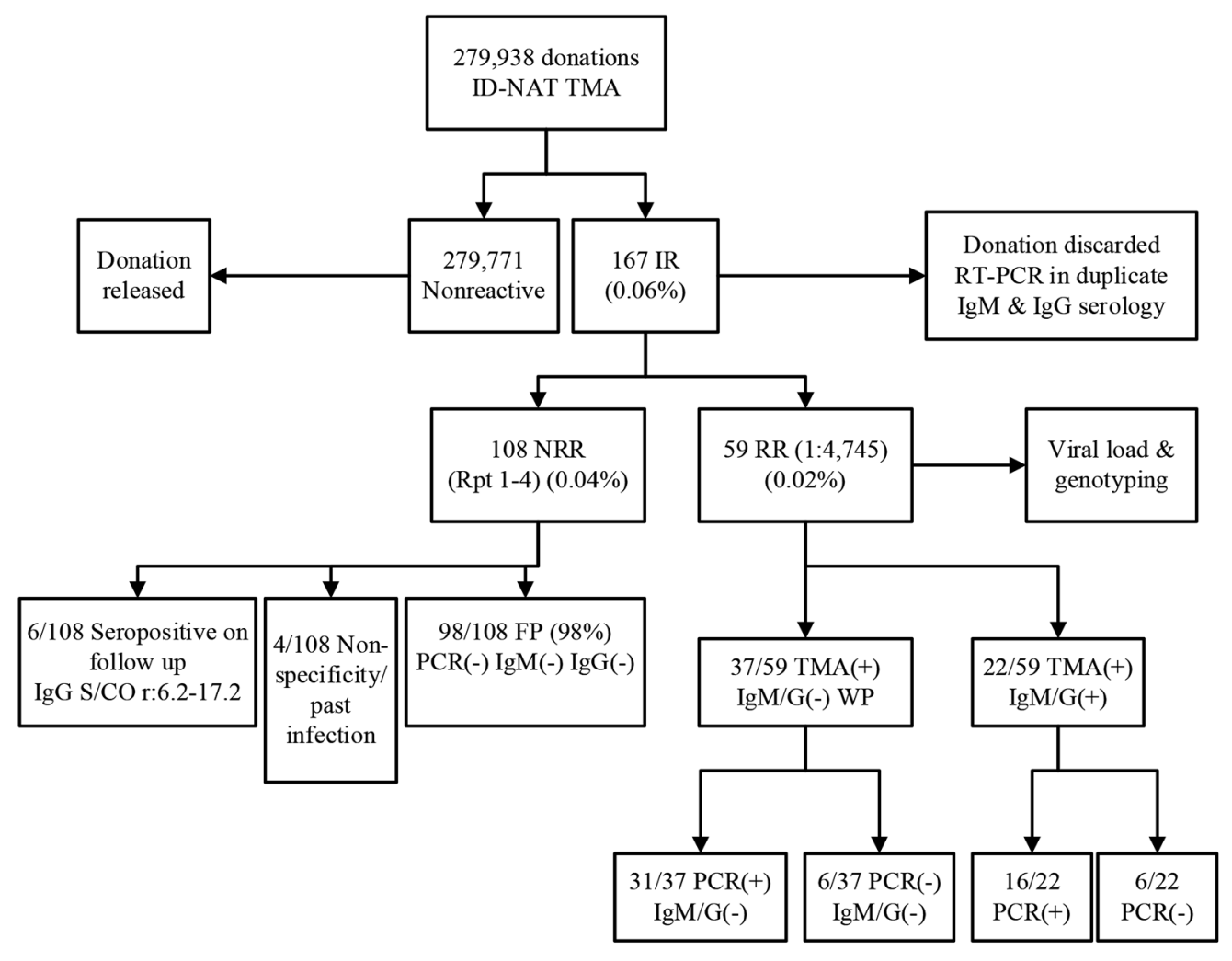

Fig. 1. IBTS HEV blood donations screening results from January 1, 2016, to December 31, 2017, using the Procleix HEV-TMA assay. All HEV initial reactive (IR) donations were referred to the National Virus Reference Laboratory (NVRL) for molecular testing using the RealStar RT-PCR assay (Altona Diagnostics) and for anti-HEV IgM and IgG serology testing using the Wantai IgM and IgG assays (Fortress Diagnostics). All IR undergo repeat testing of 2 additional replicates (Rpt 1 and 2); if either Rpt 1 and/or Rpt 2 are reactive, a repeat reactive (RR) result is assigned. All RR un- dergo additional viral load and genotyping as performed by the Virus Reference Department, Public Health England (PHE), UK, and/or Department of Viral Diagnostics, Sanquin Blood Services, the Netherlands. If Rpt 1 and 2 are nonreactive after IR, a third and fourth replicate are tested (Rpt 3 and 4); non-RR (NRR; replicates 1-4 are all nonreactive). -, negative result; +, positive result; FP, false positive; WP, window period; S/CO, sample to cut-off ratio; $\operatorname{IgM} / \mathrm{G}(-)$, IgM and/or IgG result negative; $\operatorname{IgM} / \mathrm{G}(+)$, IgM and/or IgG result positive. according to the majority of responders requires additional data and analyses" with the preferred solution being the eradication of HEV from environmental sources [6]. No other mandatory regulatory requirements exist.

The earliest adopters of HEV screening for S/D-treated plasma included the French (November 27, 2012) [7] and Dutch (January 2013) [8] blood services. On January 1, 2016, the Irish Blood Transfusion Service (IBTS) implemented universal individual donation (ID)-NAT testing for HEV-RNA. Several factors contributed to this decision. Firstly, seroprevalence and RNA incidence amongst Irish blood donors (1:5,000 donations) [9] and, secondly, the limitations of the Donor Health and Lifestyle Questionnaire in identifying asymptomatic HEVinfected donors. Ethical and legal obligations to protect recipients were also considered.
The emergence of HEV genotype (GT) 3 infection in donor populations is influenced by complexities in the agri-food industry including animal husbandry, slaughter, processing, and distribution. The European Food Safety Authority (EFSA) has issued advisory recommendations in relation to HEV as a food-borne pathogen, acknowledging that "the level of awareness of HEV risk associated with pig meat products and other reservoirs and sources is low" [2]. The European Association for the Study of the Liver (EASL) has recommended that "immunocompromised individuals and those with chronic liver diseases avoid consumption of undercooked meat (pork, wild boar, and venison) and shellfish" [10]. In addition, EASL also recommends that risk assessment and cost-effectiveness studies inform decisions regarding the screening of blood donors for HEV by NAT. 
By determining HEV-RNA incidence in EU donor populations, the benefit of implementing screening can be assessed [11]. This review article will discuss HEVRNA blood donor screening in EU countries and summarise RNA detection rates, viral load (VL), and prevalent GT in addition to mini-pool (MP) size, commercial assays used, and testing strategies. We will compare IDNAT results from Ireland to MP strategies and discuss results in the context of HEV transmissibility of blood components.

\section{Results of Irish Blood Donor Screening from 2016 to 2017}

Ireland performs universal ID-NAT screening using the Procleix ${ }^{\circledR}$ HEV transcription-mediated amplification (TMA) assay. Funding for HEV screening was sourced from the Irish Department of Health for an initial 3-year period (2016-2018). Resources for an additional 3 years were recently approved (2019-2021). An ID-NAT screening strategy is more costly than a MP approach [12]. However, the IBTS decision to screen for HEV-RNA by ID-NAT was primarily because of existing laboratory processes for blood-borne virus (2009) screening. A universal approach was deemed most appropriate because of the logistic challenges surrounding selective donation testing. Furthermore, as a smaller blood establishment (approximately 145,000 donations/year) with limited economies of scale, significant cost savings are not necessarily achievable by adopting either MP or selective testing. Since testing began, the IBTS has interdicted 59 viraemic donations of which a proportion are likely to have transmitted HEV infection to at risk recipients. In addition, HEV screening continues to provide Ireland and the wider blood transfusion community with valuable donor and viral surveillance data.

Our screening algorithm and results of testing from January 1, 2016, to December 31, 2017, are shown in Figure 1. Of the 167 initial reactive samples (IR), 59 tested repeat reactive (RR). The majority of confirmed cases $(37 / 59 ; 63 \%)$ were categorised as antibody-negative window period infections. Of note, 6 of these donor samples tested negative for HEV-RNA by PCR, but evidence of seroconversion on follow-up testing confirmed acute $\mathrm{HEV}$ infection. These results confirm that the TMA assay is a sensitive tool in detecting early acute infection. Twenty-two out of 59 RR donations (37\%) had serological evidence of $\mathrm{HEV}$ infection at some time (IgM and/or IgG reactivity). The remaining 108 of 167 donation samples were IR but negative after multiple replicates; termed non-repeat reactives. The majority of these $(98 / 108 ; 91 \%)$ were categorised as false positives based on subsequent serological and molecular testing. A further $6 / 108$ donors
Table 1. HEV reactivity rates in Irish blood donors according to age group

\begin{tabular}{llll}
\hline Age group & $\begin{array}{l}\text { Donations } \\
\text { screened negative }\end{array}$ & $\begin{array}{l}\text { HEV } \\
\text { RNA(+) }\end{array}$ & $\begin{array}{l}\text { HEV RNA(+), \% } \\
\text { (donation rate) }\end{array}$ \\
\hline 18-24 years & 28,386 & 12 & $0.042(1: 2,367)$ \\
25-34 years & 54,493 & 13 & $0.024(1: 4,193)$ \\
35-44 years & 66,397 & 15 & $0.023(1: 4,427)$ \\
45-65 years & 130,603 & 19 & $0.014(1: 6,875)$ \\
\hline Total & 279,879 & 59 & $0.021(1: 4,745)$ \\
\hline
\end{tabular}

were ultimately categorised as true positives based on the progression of HEV serology over the follow-up period. Four donors had weak IgG reactivity at the time of donation (sample to cut-off ratio, $\mathrm{S} / \mathrm{CO},<1.9$ ) and again at follow-up $(\mathrm{S} / \mathrm{CO}<2.5)$ suggesting either evidence of distant infection or false/non-specific reactivity in the assays, as reported previously [13]. The rate of HEV infection in blood donors was variable over time. We observed periods without any positive cases interspersed with episodes of higher reactivity. As further data on the interaction between animals, food, and human infection become available, the cause of this periodicity may become apparent. In the 2-year time frame, the median age of Irish HEV-positive donors was 37 years (range: 18-66) with $12 / 59$ donors falling in the 18 - to 24 -year age range (our smallest donor cohort; $p=0.02$; Table 1 ). In contrast to Irish donors, the majority of Dutch HEV-RNA-positive donors were in the older 51- to 60-year age category [representing their largest cohort of donors; Hogema B., pers. commun.]. In addition, in France and Scotland for example, the reported median age of HEV-RNA-positive donors is 50 years (range: 25-61) [7] and 47 years (range: 21-69) [14], respectively.

An ID-NAT screening strategy identifies donations with even low-level viraemia [12]. Of the 59 Irish RR donations, $56(95 \%)$ had a quantifiable VL, and of those 21/56 (37.5\%) had a VL $<100 \mathrm{IU} / \mathrm{mL}$ (Fig. 2). The distribution of Irish donor VL data is similar to that which has been reported by Tedder et al. [1] although with MP-24, a smaller proportion of donors with $\mathrm{VL}<100 \mathrm{IU} / \mathrm{mL}$ was described (2.5 vs. $37.5 \%)$. To assess the performance of a MP-24 strategy, the IBTS conducted experiments using sample aliquots $(5 \mathrm{~mL})$ collected from the fresh-frozen plasma components (FFP) associated with the 2016 HEV-RNA-positive donor cohort $(n=34)$. Plasma aliquots were de-archived from $-30^{\circ} \mathrm{C}$ storage and thawed for $10 \mathrm{~min}$ in a $25^{\circ} \mathrm{C}$ water bath before vortexing briefly to homogenise the plasma. Tubes were then spun for 10 min at 3,000 rpm. Dilution series were prepared using plasma negative for other infectious disease markers at a 1:24 dilution (comprising $100 \mu \mathrm{L}$ of HEV-RR plasma and $2,300 \mu \mathrm{L}$ of negative plasma). Dilutions were then vor- 


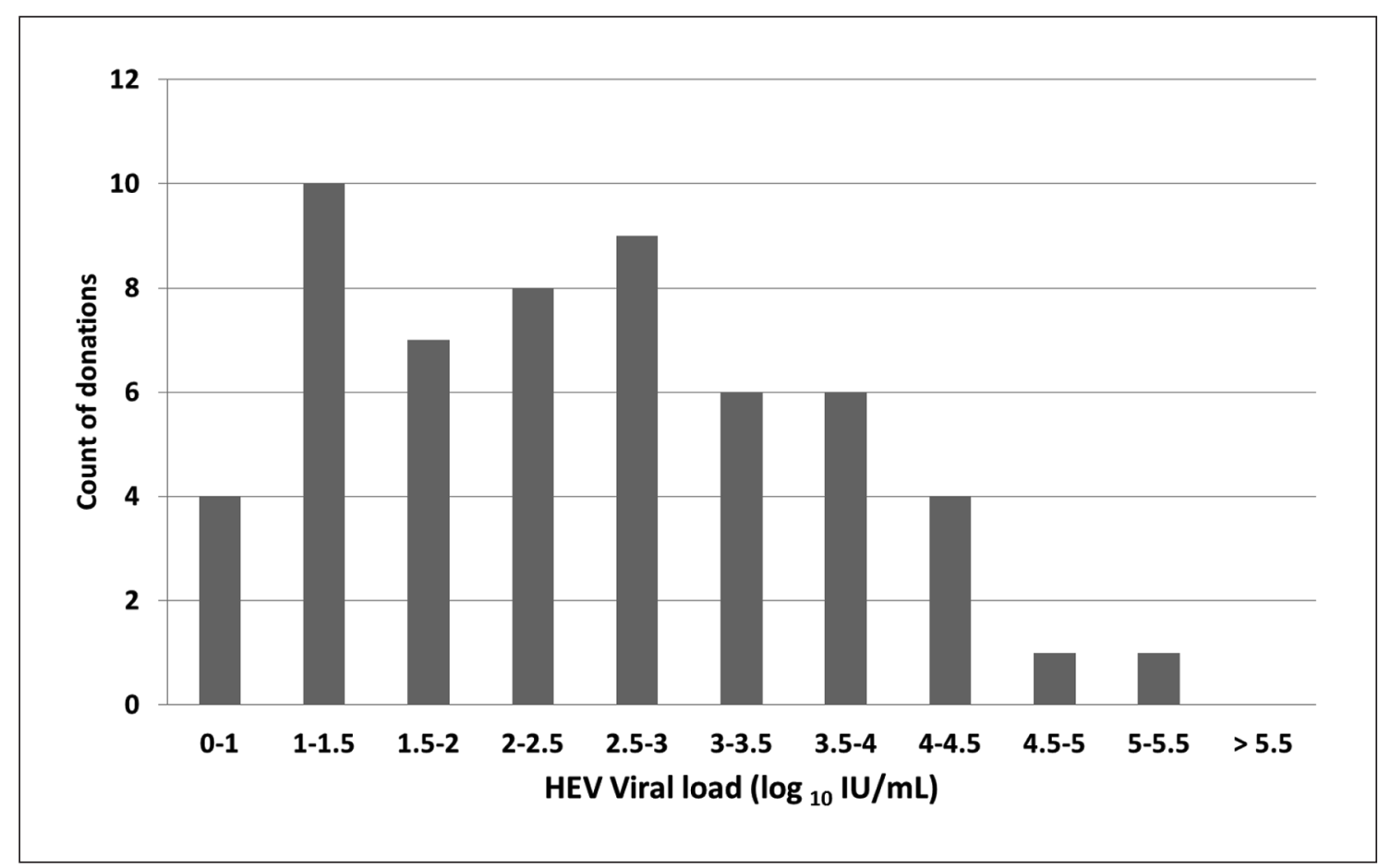

Fig. 2. Distribution of donor viral load $(n=56)$.

texed briefly and centrifuged at 3,000 rpm for $10 \mathrm{~min}$. Dilutions were tested in replicates of 2 before discarding. Based on $95 \%$ limit of detection (LoD) of $7.89 \mathrm{IU} / \mathrm{mL}$ for the Procleix HEV assay ${ }^{\circledR}$ [15], a MP-24 strategy would hypothetically detect a VL of $\geq 190 \mathrm{IU} / \mathrm{mL}$. In this MP-24 study, 25/34 donor samples with $\mathrm{VL} \geq 130 \mathrm{IU} / \mathrm{mL}$ were reactive in duplicate. The remaining 9 samples which tested nonreactive in duplicate in MP-24 had a VL range of $11-64 \mathrm{IU} / \mathrm{mL}$.

\section{Overview of EU Blood Donor Screening Methods and Strategies}

Of the $28 \mathrm{EU}$ member states, 8 countries have implemented HEV-RNA donor screening (Table 2; November 2012 to April 2018) [16-23]. Six of the remaining $20 \mathrm{EU}$ countries have published blood donor data. The National Blood Transfusion Service in Malta plans to introduce selective ID-NAT-HEV screening in 2019 [Bonello N., pers. commun.]. Both Denmark and Sweden have evaluated the incidence of HEV-RNA in their blood donors and do not plan to implement HEV screening [22-24]. In Denmark, TT-HEV was not reported in recipients who received blood components from $\mathrm{HEV}$-infected donors with low VL [22]. However, screening of blood for immunocompromised patients is still under consideration. As far as the authors are aware at the time of publication, the remaining $12 \mathrm{EU}$ countries have no imminent plans
Table 2. HEV-RNA screening of blood donors in the 28 EU countries

\begin{tabular}{lll}
\hline $\begin{array}{l}\text { Donor screening } \\
\text { implemented in } \\
8 \text { EU countries }\end{array}$ & $\begin{array}{l}\text { Donor screening not implemented in } \\
\text { 20 EU countries }\end{array}$ \\
\cline { 2 - 3 } $\begin{array}{ll}\text { decision taken not } \\
\text { to screen }(n=2 / 20)\end{array}$ & $\begin{array}{l}\text { donor research } \\
\text { completed }(n=6 / 20)\end{array}$ \\
\hline Ireland & Denmark [22] & $\begin{array}{l}\text { Italy [16] } \\
\text { PK }\end{array}$ \\
$\begin{array}{l}\text { France } \\
\text { The Netherlands }\end{array}$ & & $\begin{array}{l}\text { Poland [17] } \\
\text { Pertugal [18] }\end{array}$ \\
$\begin{array}{l}\text { Germany } \\
\text { Spain } \\
\text { Austria }\end{array}$ & Galta [19] \\
Luxembourg & & Belgium [21] \\
\hline
\end{tabular}

to implement screening. Of note, the Swiss Red Cross implemented universal HEV-RNA screening of blood donors in November 2018 (MP-24 using the Cobas HEV assay $^{\circledR}$ ) with a required detection limit of $450 \mathrm{IU} / \mathrm{mL}$ in individual donations [25].

The 8 EU countries screening blood donors for HEVRNA (including GT and VL assessment) are outlined in Table 3 [7, 8, 14, 26-31]. The highest donor reactivity rates are reported by Germany, France, and the Netherlands. HEV screening strategy is broadly divided into 2 categories: universal (U) screening of all blood donations (which is carried out in Ireland, the UK, and the Netherlands) and selective (S) screening (which is performed in 
Table 3. HEV-RNA reactivity rates in blood donations across 8 EU countries

\begin{tabular}{|c|c|c|c|c|c|c|c|c|}
\hline EU country & Time frame & $\begin{array}{l}\text { Testing } \\
\text { strategy }\end{array}$ & $\begin{array}{l}\text { Donations } \\
\text { screened, } \\
n\end{array}$ & $\begin{array}{l}\text { Sample/ } \\
\text { MP size }\end{array}$ & $\begin{array}{l}\text { HEV } \\
\text { RNA+, } \\
n\end{array}$ & $\begin{array}{l}\text { Donation } \\
\text { reactivity rate } \\
\text { (\%) }\end{array}$ & $\begin{array}{l}\text { Genotype } \\
\text { (GT) }\end{array}$ & $\begin{array}{l}\text { Donor viral load range, } \\
\mathrm{IU} / \mathrm{mL}\end{array}$ \\
\hline Ireland $\uparrow$ & $\begin{array}{l}\text { January 1, 2016, to } \\
\text { December 31, } 2017\end{array}$ & $\mathrm{U}$ & 279,938 & ID-NAT & 59 & 1 in $4,745(0.02)$ & Mostly $3 \mathrm{c} ; 3 \mathrm{e}$ & $14-260,000$ \\
\hline UK [26] & January 1 to December 31, 2017 & $S+U$ & $1,598,001$ & $\begin{array}{l}\text { MP-16/ } \\
-24\end{array}$ & 335 & 1 in $4,771(0.02)$ & $\mathrm{N} / \mathrm{A}$ & N/A \\
\hline UK, England [26] & January 1 to December 31, 2017 & $S+U$ & $1,330,925$ & MP-24 & 281 & 1 in $4,736(0.02)$ & $\mathrm{N} / \mathrm{A}$ & N/A \\
\hline UK, England [27] & $\begin{array}{l}\text { October 8, 2012, to } \\
\text { September 30, } 2013\end{array}$ & $\mathrm{U}^{1}$ & 225,000 & MP-24 & 79 & 1 in $2,848(0.035)$ & $\begin{array}{l}\text { Most (43/54) } \\
\text { GT3(abcdhij) }\end{array}$ & $50-2,370,000$ \\
\hline UK, Scotland [26] & January 1 to December 31, 2017 & $\mathrm{~S}+\mathrm{U}$ & 149,869 & $\begin{array}{l}\text { MP-16/ } \\
-24\end{array}$ & 40 & 1 in $3,747(0.03)$ & $\mathrm{N} / \mathrm{A}$ & N/A \\
\hline UK, Scotland [14] & February 2016 to May 2017 & $S+U$ & 94,302 & MP-24 & 38 & 1 in $2,481(0.04)$ & Mostly $3 c ; 3 e$ & N/A \\
\hline UK, Wales [26] & January 1 to December 31, 2017 & $S+U$ & 77,722 & $\begin{array}{l}\text { MP-16/ } \\
-24\end{array}$ & 9 & 1 in $8,636(0.01)$ & $\mathrm{N} / \mathrm{A}$ & $\mathrm{N} / \mathrm{A}$ \\
\hline $\begin{array}{l}\text { UK, Northern } \\
\text { Ireland [26] }\end{array}$ & January 1 to December 31, 2017 & $S+U$ & 39,485 & MP-24 & 5 & 1 in $7,897(0.01)$ & N/A & N/A \\
\hline France $[7,28]$ & $2012 ; 2014-2015$ & $S+U$ & 95,334 & $\begin{array}{l}\text { ID-NAT } \\
\text { MP-6/-96 }\end{array}$ & 59 & 1 in $1,616(0.062)$ & Mostly 3f; 3c & N/A \\
\hline France [7] & November 27, 2012 & S & 53,234 & MP-96 & 24 & 1 in $2,218(0.045)$ & $\begin{array}{l}3 \mathrm{f}(59 \%) \\
3 \mathrm{c}(36 \%)\end{array}$ & $468-5,155,800$ \\
\hline France [28] & $\begin{array}{l}\text { November 1, 2014, to } \\
\text { September } 30,2015\end{array}$ & S & 36,889 & MP-6 & 28 & 1 in $1,317(0.075)$ & 3 & N/A \\
\hline France [28] & June and July 2015 & $\mathrm{U}^{1}$ & 5,211 & ID-NAT & 7 & 1 in $744(0.13)$ & $\mathrm{N} / \mathrm{A}$ & $<100-1,935$ \\
\hline The Netherlands $[8]^{2}$ & 2013-2018 & $S+U$ & 397,290 & $\begin{array}{l}\text { MP-24/ } \\
-96 /-192\end{array}$ & 200 & 1 in $1,987(0.05)$ & Mostly 3c; 3f & N/A \\
\hline The Netherlands [8] & January 2013 to December 2014 & S & 59,474 & $\begin{array}{l}\text { MP-96/ } \\
-192\end{array}$ & 45 & 1 in $1,322(0.076)$ & Mostly 3c; 3f & $80-2,320,000$ \\
\hline The Netherlands ${ }^{2}$ & July 3, 2017, to April 19, 2018 & $\mathrm{U}$ & 337,816 & MP-24 & 155 & 1 in $2,179(0.046)$ & Mostly $3 c ; 3 f$ & $10-25,700,000$ \\
\hline Germany $[29,30]$ & $2015-2017$ & $\mathrm{U}^{1}$ & 254,261 & MP-24/-96 & 205 & 1 in $1,241(0.08)$ & $\mathrm{N} / \mathrm{A}$ & N/A \\
\hline Germany [29] & January 2015 to July 2017 & $\mathrm{U}^{1}$ & 235,524 & MP-96 & 182 & 1 in $1,294(0.077)$ & 3 & $<25-520,000$ \\
\hline Germany [30] & October 2016 to May 2017 & $\mathrm{U}^{1}$ & 18,737 & MP-24 & 23 & 1 in $815(0.12)$ & $\begin{array}{l}\text { Most (6/7) } \\
\text { GT3 (abcdhij) }\end{array}$ & $120-11,200,000$ \\
\hline Spain $^{2}$ & $\begin{array}{l}\text { November } 1,2017 \text {, to } \\
\text { April } 30,2018\end{array}$ & $\mathrm{U}^{1}$ & 111,534 & MP-16 & 29 & 1 in $3,846(0.026)$ & Mostly 3f; 3c & $<40$ to $>1,000,000$ \\
\hline Austria [31] & 2016-2017 & S & 155,691 & MP-96 & 29 & 1 in $5,369(0.02)$ & 3 & $\mathrm{~N} / \mathrm{A}$ \\
\hline Luxembourg & 2017 & S & 914 & MP-96 & 0 & 0 & $\mathrm{~N} / \mathrm{A}$ & N/A \\
\hline $\begin{array}{l}\text { Total for } 8 \mathrm{EU} \\
\text { countries }\end{array}$ & Nov 2012 to Apr 2018 & $\mathrm{U}+\mathrm{S}$ & $3,210,731$ & All & 1,033 & 1 in $3,109(0.032)$ & $\begin{array}{l}\text { Mostly 3c; 3f, } \\
3 \mathrm{e}\end{array}$ & $14-25,700,000$ \\
\hline
\end{tabular}

$\uparrow$, unpublished data; $\mathrm{U}$, universal screening; S, selective screening; ID, individual donation; MP, mini-pool size; +, positive; N/A, data not available.

${ }^{1}$ Universal donation screening in some regions within the EU country. ${ }^{2}$ Personal communication (see text for details).

blood establishments in France, Austria, and Luxembourg). A selective screening strategy allows for an inventory of HEV-negative blood selected for those patients at highest risk of complicated TT-HEV. In Spain and Germany, blood donations collected within specific regions, Catalonian region; HDZ (Heart and Diabetes Centre) North Rhine-Westphalia, Ruhr University of Bochum, and University Medical Centre Hamburg-Eppendorf, respectively, are universally screened for HEV-RNA. Samples can be screened in MP or ID format. The most commonly used assays in blood screening are the Procleix HEV assay (95\% LoD $7.89 \mathrm{IU} / \mathrm{mL}$; Panther testing system; Grifols Diagnostic Solutions, Inc., developed in collaboration with Hologic, Inc.) [previously described 11, 15] and the Cobas HEV PCR assay (95\% LoD 18.6 IU/mL;
Cobas 6800/8800 systems; Roche Molecular Systems, Inc.) [28]. The RealStar HEV RT-PCR kit ${ }^{\circledR}$ for donation screening (95\% LoD $4.7 \mathrm{IU} / \mathrm{mL}$; Altona Diagnostics, Hamburg, Germany) is also used by some blood establishments [32].

\section{The United Kingdom}

In 2017 across the UK blood services, 1.6 million donations were screened for HEV-RNA and $335 \mathrm{HEV}$ infections were identified (1:4,771 or 21 cases per 100,000 donations tested) (Table 3) [26]. The NHS Blood and Transplant England employs a MP-24 strategy using the Cobas $\mathrm{HEV}$ assay. A selective $\mathrm{HEV}$-screened inventory was maintained from spring 2016 until a universal screening strategy was implemented in April 2017 [26]. In the 
Welsh Blood Service (WBS), selective screening was first implemented in January 2016 in MP-24 using the Cobas HEV assay and was updated to universal screening in March 2017 [Jones A., pers. commun.]. The Procleix HEV assay was introduced by WBS in MP-16 in July 2017. In September 2017, the Scottish National Blood Transfusion Service (SNBTS) also introduced the Procleix HEV assay in MP-16 [1:4,000 donations; Simpson C., pers. commun.]. Prior to this, a selective MP-24 screening strategy was employed using the Cobas HEV assay. In 2017, two TT-HEV cases were reported, 1 confirmed and 1 probable, from unscreened donations [33]. HEV-GT $3 c$ appears to predominate in HEV-infected UK blood donors, but there are limited GT and VL (range: 50-2,370,000 IU/mL) data available.

\section{France}

France was one of the first EU countries to implement selective HEV testing of donations used to manufacture pooled plasma components [7]. A number of HEV screening strategies have been employed between 2012 and 2015, including ID-NAT, MP-6, and MP-96, yielding an overall reactivity rate of 1:1,616 donations (Table 3). MP-96 screening (2012; RealStar RT-PCR kit, Altona; 1:2,218) was reduced to MP-6 in 2014 (RealStar RT-PCR kit, Altona; $1: 1,317$ ) [28]. Since January 2018, selective MP-6 screening is performed using the Procleix HEV assay [Gallian P., pers. commun.]. HEV-GT 3f was the most commonly observed subtype in confirmed cases with wide variation in reported VL (range: $<100-5,155,800$ ). The first TT-HEV case (GT 3f; RBC transfused to a 7-year-old boy) was reported in 2006 [34]. From 2006 to 2016, 30 TTHEV cases were reported by the Haemovigilance systems in France with various blood components implicated [35]. Since 2014, there have been no reported TT-HEV cases associated with plasma components.

\section{The Netherlands}

From 2013 to 2018, 400,000 donations were screened in selective and universal format with $200 \mathrm{HEV-con-}$ firmed cases detected $(1: 1,987)$ using 3 different MP sizes (Table 3). In 2013 and 2014, donations to be used in the production of S/D-treated plasma were screened in pools of 96 and 192 for HEV-RNA using a PCR-based assay. In these 2 years, a high incidence of $\mathrm{HEV}$ infection at 1 in 762 donations $(78 / 59,474$ donations) was observed [8]. On December 2, 2016, the Minister for Health approved the implementation of universal HEV screening of the blood supply [36]. In July 2017, HEV-NAT screening in MP-24 using the Cobas HEV assay on the Roche Cobas 6800 testing system was initiated. After screening over 300,000 donations in a 9-month period (April 19, 2017), the confirmed RNA-positive rate was 1 in 2,179 donations $(0.046 \%)$. Confirmatory testing is carried out using an in-house quantitative PCR assay [previously reported: 37]. Based on MP-24 screening, all 155 individual donations were reactive when tested by PCR (mostly GT 3c; $\mathrm{VL}$ range: $10-25,700,000 \mathrm{IU} / \mathrm{mL}$ ). Of the donations, $73 \%$ were IgM and IgG seronegative, indicating acute infection [Hogema B., pers. commun.].

\section{Germany}

From 2015 to 2017, within specific geographical regions, over 250,000 donations were screened universally in MP-24/-96 yielding 205 confirmed HEV-positive donations $(1: 1,241)$ (Table 3). In 2015, the German Advisory Committee Blood [38] commented that severely immunosuppressed patients would "potentially" benefit from HEV-RNA-negative blood, bearing in mind that further research in relation to $\mathrm{HEV}$ infection and disease severity is warranted. At the time, they also commented that "a HEV-NAT with a sensitivity of approximately 100 $\mathrm{IU} / \mathrm{mL}$ would be necessary to achieve a considerable reduction of HEV transmissions." The following year, an increase in the number of HEV infections was reported to national surveillance systems with $84 \%$ of HEV infections being acquired locally (HEV is a notifiable disease since 2001) [39]. The Paul Ehrlich Institute (PEI) has indicated the likely introduction of HEV-NAT screening as a mandatory requirement for RBC and platelet concentrates from January 1, 2020, and for FFP from January 1 , 2021 [40]. A recent simulation study estimated that an $80 \%$ reduction in expected HEV transmissions could be achieved using a NAT assay with a $95 \%$ LoD of $20 \mathrm{IU} / \mathrm{mL}$ in MP-96. [41]. In comparison, a MP-24 strategy would reduce transmissions by $90 \%$ (MP-6 not assessed). Several hospital blood establishments are providing HEVscreened blood components including HDZ, Ruhr University of Bochum, and University Medical Centre Hamburg-Eppendorf (Table 3). In the latter centre [30], retrospective ID testing of previous MP-24-negative donation samples from HEV -positive donors $(n=23 / 18,737)$ identified 4 viraemic donors (VL range: 760-4,500 IU/ $\mathrm{mL})$ associated with transfused blood components $(n=$ 14). In this instance, 2 recipients tested HEV-RNA positive (550 and 70,000 IU/mL), and TT-HEV could not be excluded in 3 other recipients. Six out of 7 HEV sequences were identified as belonging to GT3 "Group 2" with low VL detected in $15 / 23$ of donors $(\leq 1,000 \mathrm{IU} / \mathrm{mL})$.

\section{Spain}

Between November 2017 and April 2018, over 110,000 donations in the Catalonian region of Spain have been tested with the Procleix HEV assay in MP-16 with a reactivity rate of 1 in 3,846 donations $(68 \%$ are $\operatorname{IgM} / \operatorname{IgG}$ negative) [Sauleda Oliveras S., pers. commun.]. The VL ranged from $<40$ to $>1,000,000 \mathrm{IU} / \mathrm{mL}$ with GT 3 f largely described (Table 3). Blood donor research in south cen- 
tral Spain (October 2017 to March 2018) identified 1 in 1,524 HEV-RNA-positive donations (MP-8 using RTPCR; $0.06 \%$ ) with VL ranging from $~ 10,000$ to 2,000,000 $\mathrm{IU} / \mathrm{mL}$ [42]. In Spain, 1 confirmed case of TT-HEV infection (GT 3f) has been reported [43].

\section{Discussion}

Since November 2012, over 3.2 million EU donations have been screened for HEV-RNA with an overall rate of 1 in 3,109 HEV-RNA-positive donations (Table 3) bearing in mind that the results of incidence studies are influenced by MP size and LoD of the assay applied. Based on donation screening, donor VL ranged from $<100$ to $>25,000,000 \mathrm{IU} / \mathrm{mL}$ with GT $3 \mathrm{c}$ being the most commonly reported subtype. In 2017, $8 \mathrm{EU}$ countries were screening blood donations for HEV-RNA as compared to 2 countries in 2014. Factors influencing the decision to adopt either a MP versus ID and universal versus selective testing approach include risk assessment, resource availability, health economics, as well as reputational, political, and other influences. The majority of EU countries $(n=7)$ who have implemented HEV screening have opted for a MP approach. Large MPs are effective in removing from the blood supply those donations that are most likely to transmit HEV. For those blood establishments which have implemented more costly MP of MP-6/-24, the risk of issuing a $\mathrm{HEV}$-contaminated product is even smaller. Universal screening has been implemented by Ireland, the UK, and the Netherlands. Whilst selective blood donation inventories are challenging to manage, having a supply of HEV-tested blood components available mitigates the risk of TT-HEV in the most vulnerable patients.

There have been several recent studies investigating the infectivity of HEV-contaminated blood components [1, 12, $27,29,44]$. The likelihood of transmission is influenced by the donor VL and the residual plasma volume of the blood component, i.e., the infectious dose. This information has been crucial in informing decisions by various blood services about which testing strategy should be adopted. Dreier et al. [29] recently estimated the VL in different viraemic blood components and in HEV-RNA-positive donors and concluded lower plasma volume components (RBC) are least likely to transmit compared to high plasma volume components (FFP). The median infectious dose resulting in HEV infection reported by Dreier et al. [29] was 520,000 IU irrespective of recipient immune status. Data on infectious dose from Tedder et al. $[1,44]$ suggest that infection is unlikely to occur at an infectious dose of $<19,000 \mathrm{IU}$ [27]. Applying this information to data generated in an IBTS MP-24 experiment (VL of $130 \mathrm{IU} / \mathrm{mL}$ detected in 2/2 replicates), we could infer that a low plasma volume compo- nent (e.g., RBC with $13.5 \mathrm{~mL}$ plasma) tested in a MP-24 is unlikely to contain an infectious dose (i.e., 1,800 IU) sufficient to cause TT-HEV. However, for an apheresis platelet donation ( $300 \mathrm{~mL}$ plasma volume) equating to a maximum infectious dose of $39,000 \mathrm{IU}$, there is a reasonable expectation of TT-HEV.

Another important factor to consider when introducing HEV screening is the sensitivity of the assay in combination with MP size (no regulatory policies are in place). The recent PEI recommendations to utilise EU-marketed HEV-NAT assays with a detection limit of 2,000 IU/mL for individual donations implies a MP-96 screening strategy (equating to an ID detection limit of $20 \mathrm{IU} / \mathrm{mL}$ ) would be acceptable for blood donor screening [40]. Vollmer et al. [32] reports a MP-96 detection limit of $452 \mathrm{IU} / \mathrm{mL}$ (95\% LoD 4.7 IU/mL using the RealStar RT-PCR kit) in contrast to colleagues [30] with a "theoretical" MP-24 detection limit of $446.4 \mathrm{IU} / \mathrm{mL}$ (95\% LoD 18.6 IU/mL using the Cobas HEV assay) for single donors. If we extrapolate from the Irish testing experience to date, 59\% ( $n=35 / 59$ with $\mathrm{VL}<450 \mathrm{IU} / \mathrm{mL}$ ) of our $\mathrm{HEV}$-reactive donations with $\mathrm{VL}<450 \mathrm{IU} / \mathrm{mL}$ would not have been interdicted by either of these screening strategies. However, the number of TT-HEV cases that would have resulted from these contaminated components which screened negative by MP is difficult to estimate. The situation is further complicated by the knowledge that large MP screening strategies (MP-24) have identified viraemic donations below the calculated LoD (120 and $140 \mathrm{IU} / \mathrm{mL}$ ) [30].

Although the burden of disease from low viral load/ infectious dose blood components appears to be small especially in the case of immunocompetent recipients, cases have been reported in the literature. Indeed, chronic $\mathrm{HEV}$ infection has been reported in an immunocompetent seropositive individual with no apparent relation to blood transfusion [45]. In Germany, probable HEV infection developed in an immunocompetent recipient who received an apheresis platelet transfusion from a single donor (120 IU/mL HEV-RNA/mL plasma; infectious dose of 8,892 IU) [46]. In France, HEV infection in an immunocompetent trauma patient linked to an unscreened platelet pool product was described [47]. In Spain, a TT$\mathrm{HEV}$ infection occurred in an immunocompetent individual from a RBC transfusion (donor archive sample VL was 75,000 IU/mL) [42]. These cases suggest we have much yet to learn in relation to recipient factors leading to chronic HEV infection. It is important for laboratories, surveillance networks, as well as blood establishments to participate and share information on HEV to identify possible EU control points. HEVNet is a global laboratory surveillance network of hepatitis E experts who collaborate to monitor the clinical and molecular epidemiology of HEV in Europe, including the source, evolution, and spread of HEV (www.rivm.nl/en/hevnet) [48]. 


\section{Conclusions}

Research and surveillance studies, expert groups, institutional bodies, and regulators have documented the emergence of HEV and demonstrated it to be a relatively frequent transfusion-transmissible agent in European blood donors. HEV is present not only in the food we consume but also in our environment [49]. The response by blood services to HEV risk is influenced by myriad epidemiological, economic, and political factors. In some countries, blood screening for HEV has not been considered necessary at this time. Universal HEV-ID-NAT testing almost completely excludes donations from asymptomatic viraemic donors but is costly. Most EU countries have opted to implement a MP screening approach to reduce transmission risk. The elimination of HEV will require a "one health" approach, whereby the interrelationships between animals, food, human infection, and the environment are elucidated, and the optimal control points are then identified [50].

\section{Acknowledgements}

We thank the following for their contribution to this review article: the laboratory scientific teams of IBTS NAT (J. Murphy, L. Burke, F. Young, A. Duane, K. Nolan, C. Rogers, M.-L. McLaughlin, M. Maher, R. Corcoran, N. Haughian, H. Fitzpatrick, and D. Boniecka) and IBTS Virology, J. O’Riordan (IBTS), B.M. Hogema and H.L. Zaaijer (Sanquin Blood Service), A. Jones (WBS), C. Simpson (SNBTS), P. Gallian (EFS, Etablissement Français du Sang), S. Sauleda Oliveras (Catalonian Blood Service), C. Jungbauer (Austrian Red Cross), C. De Pauw (Luxembourg Red Cross), N. Bonello (Malta), and A. Kinsella (statistician).

We would also like to thank the laboratory teams in the National Virus Reference Laboratory (NVRL) in University College Dublin, the Virus Reference Department in Public Health England (PHE) laboratories, and the Department of Viral Diagnostics, Sanquin Blood Services.

\section{Statement of Ethics}

The authors have no ethical conflicts to disclose.

\section{Disclosure Statement}

The authors have no conflicts of interest to declare.

\section{References}

1 Tedder RS, Ijaz S, Kitchen A, Ushiro-Lumb I, Tettmar KI, Hewitt P, et al. Hepatitis E risks: pigs or blood-that is the question. Transfusion. 2017 Feb;57(2):267-72.

2 Ricci A, Allende A, Bolton D, Chemaly M, Davies R, Salvador Fernandez Escamez P, et al. Public Health risks associated with hepatitis $\mathrm{E}$ virus (HEV) as a food-borne pathogen. European Food Safety Authority (EFSA) panel on Biological Hazards (BIOHAZ). EFSA J. 2017;15(7):4886.

3 The European Directorate for the Quality of Medicines and Healthcare (EDQM). European Pharmacopoeia. 8th ed. Strasbourg: Council of Europe; 2016.

4 Aspinall EJ, Couturier E, Faber M, Said B, Ijaz S, Tavoschi L, et al; oin behalf of the Country Experts. Hepatitis E virus infection in Europe: surveillance and descriptive epidemiology of confirmed cases, 2005 to 2015. Euro Surveill. 2017 Jun;22(26):1-8.

5 Domanović D, Tedder R, Blümel J, Zaaijer H, Gallian P, Niederhauser C, et al. Hepatitis E and blood donation safety in selected European countries: a shift to screening? Euro Surveill. 2017 Apr;22(16):1-8.

6 Petrik J, Lozano M, Seed CR, Faddy HM, Keller AJ, Prado Scuracchio PS, et al. Hepatitis E. Vox Sang. 2016 Jan;110(1):93-130.

7 Gallian P, Lhomme S, Piquet Y, Sauné K, Abravanel F, Assal A, et al. Hepatitis E virus infections in blood donors, France. Emerg Infect Dis. 2014 Nov;20(11):1914-7.

8 Hogema BM, Molier M, Sjerps M, de Waal M, van Swieten $\mathrm{P}$, van de Laar T, et al. Incidence and duration of hepatitis $\mathrm{E}$ virus infection in Dutch blood donors. Transfusion. 2016 Mar; 56(3):722-8.
9 O'Riordan J, Boland F, Williams P, Donnellan J, Hogema BM, Ijaz S, et al. Hepatitis E virus infection in the Irish blood donor population. Transfusion. 2016 Nov;56(11):2868-76.

10 European Association for the Study of the Liver (EASL) Clinical Practice Guidelines on hepatitis E virus infection. J Hepatol. 2018;68: 1256-71.

11 Izopet J, Lhomme S, Chapuy-Regaud S, Mansuy JM, Kamar N, Abravanel F. HEV and transfusion-recipient risk. Transfus Clin Biol. 2017 Sep;24(3):176-81.

12 de Vos AS, Janssen MP, Zaaijer HL, Hogema BM: Cost-effectiveness of the screening of blood donations for hepatitis $\mathrm{E}$ virus in the Netherlands. Transfusion. 2017 Feb;57(2): 258-66.

13 Norder H, Karlsson M, Mellgren Å, Konar J, Sandberg E, Lasson A, et al. Diagnostic Performance of Five Assays for Anti-Hepatitis E Virus IgG and IgM in a Large Cohort Study. J Clin Microbiol. 2016 Mar;54(3):549-55.

14 Thom K, Gilhooly P, McGowan K, Malloy K, Jarvis LM, Crossan C, et al. Hepatitis E virus (HEV) in Scotland: evidence of recent increase in viral circulation in humans. Euro Surveill. 2018 Mar;23(12). doi: 10.2807/15607917.ES.2018.23.12.17-00174.

15 Procleix HEV Assay package insert, 504513 rev 002 [accessed 2019 Jan 7]. www.diagnostic.grifols.com/en/procleix-assays/productspecifications.

16 Mauceri C, Grazia Clemente M, Castiglia P, Antonucci R, Schwarz KB. Hepatitis E in Italy: A silent presence. J Infect Public Health. 2018 Jan - Feb;11(1):1-8.
17 Grabarczyk P, Sulkowska E, Gdowska J, Kopacz A, Liszewski G, Kubicka-Russel D, et al. Molecular and serological infection marker screening in blood donors indicates high endemicity of hepatitis $\mathrm{E}$ virus in Poland. Transfusion. 2018 May;58(5):1245-53.

18 Abrue-Silva J, Pereira S, Teixeira J, Oliveira R, Tomaz J, Sargento C, et al. Evidence of Recent Hepatitis E virus infection in Portuguese Blood donors. EASL Livertree International Conference 2016. Poster presentation [accessed 2018 May 2]. https://doi.org/10.1016/ S0168-8278(16)00770-4.

19 Bonello N: Hepatitis E virus in Malta [abstract]. SCISEM Life Science Research Seminar; 2017 May 22.

20 Zervou EZ, Politis CP, Hassapopoulou EH, Vini MV, Parara MP, Kavallierou LK, et al. Prevalence of hepatitis E virus (HEV) infection in blood donors and multi-transfused patients in Greece. Vox Sang. 2015;109:242-3.

21 Vercouter A-S, Van Houtte F, Verhoye L, Gonzalez Fraile I, Blanco L, Compernolle V, et al: HEV Prevalence in Flemish Blood Donations. Poster presentation. ISBT; 2018 Jun; Toronto.

22 Harritshøj LH, Holm DK, Saekmose SG, Jensen BA, Hogema BM, Fischer TK, et al. Low transfusion transmission of hepatitis $\mathrm{E}$ among 25,637 single-donation, nucleic acid-tested blood donors. Transfusion. 2016 Sep;56(9): 2225-32.

23 Baylis SA, Gärtner T, Nick S, Ovemyr J, Blümel J. Occurrence of hepatitis E virus RNA in plasma donations from Sweden, Germany and the United States. Vox Sang. 2012 Jul; 103(1):89-90. 
24 Davidson T, Ekermo B, Gaines H, Lesko B, Åkerlind B. The cost-effectiveness of introducing nucleic acid testing to test for hepatitis $\mathrm{B}$, hepatitis $\mathrm{C}$, and human immunodeficiency virus among blood donors in Sweden. Transfusion. 2011 Feb;51(2):421-9.

25 Niederhauser C, Widmer N, Hotz M, Tinguely C, Fontana S, Allemann G, et al. Current hepatitis E virus seroprevalence in Swiss blood donors and apparent decline from 1997 to 2016. Euro Surveill. 2018 Aug;23(35). https://doi.org/10.2807/1560-7917. ES.2018.23.35.1700616.

26 Safe Supplies: A year of change. Annual Review from the NHS Blood and Transplant (NHSBT)/Public Health England (PHE) Epidemiology Unit, 2017. London: Public Health England; 2018. Supplementary data tables and figures: 2017.

27 Hewitt PE, Ijaz S, Brailsford SR, Brett R, Dicks S, Haywood B, et al. Hepatitis E virus in blood components: a prevalence and transmission study in southeast England. Lancet. 2014 Nov; 384(9956):1766-73.

28 Gallian P, Couchouron A, Dupont I, Fabra C, Piquet $Y$, Djoudi R, et al. Comparison of hepatitis $\mathrm{E}$ virus nucleic acid test screening platforms and RNA prevalence in French blood donors. Transfusion. 2017 Jan;57(1):223-4.

29 Dreier J, Knabbe C, Vollmer T. TransfusionTransmitted Hepatitis E: NAT Screening of Blood Donations and Infectious Dose. Front Med (Lausanne). 2018 Feb;5:5

30 Westhölter D, Hiller J, Denzer U, Polywka S, Ayuk F, Rybczynski M, et al. HEV-positive blood donations represent a relevant infection risk for immunosuppressed recipients. Hepatol. 2018 Jul;69(1):36-42.

31 Austrian Agency for Health and Food Safety (AGES) Conference on Virus Hepatitis and the Public Health Service in Austria on 27th July 2017.

32 Vollmer T, Knabbe C, Dreier J. Knowledge Is Safety: The Time Is Ripe for Hepatitis E Virus Blood Donor Screening. Transfus Med Hemother. 2016 Nov;43(6):425-7.
33 SHOT 2017 annual report [accessed 2018 Nov 26]. https://www.shotuk.org/wp-content/uploads/myimages/SHOT-Cases-2017. pdf.

34 Colson P, Coze C, Gallian P, Henry M, De Micco P, Tamalet C. Transfusion-associated hepatitis E, France. Emerg Infect Dis. 2007 Apr;13(4):648-9.

35 ANSM (French National Agency for Medicines and Health Products Safety). 2016 Haemovigilance Report. 2017 Dec [accessed 2018 Sep 14]. www.ansm.sante.fr.

36 Health Council of Netherlands Advisory Report on 'Testing blood donations for hepatitis E virus'. No. 2018/18, The Hague, July 31, 2018 Executive summary [accessed 2018 Oct 9]. https://www.healthcouncil.nl/binaries/ healthcouncil/documents/advisoryreports/2018/07/31/testing-blood-donationsfor-hepatitis-e-virus/summary testing blood_donations_for_hepatitis_e_virus.pdf.

37 Slot E, Zaaijer HL, Molier M, Van den Hurk K, Prinsze F, Hogema BM: Meat consumption is a major risk factor for hepatitis $\mathrm{E}$ virus infection. PLoS One. 2017 Apr;12(4): e0176414.

38 Pauli G, Aepfelbacher M, Bauerfeind U, Blümel J, Burger R, Gärtner B, et al; German Advisory Committee Blood (Arbeitskreis Blut), Subgroup "Assessment of Pathogens Transmissible by Blood." Hepatitis E virus. Transfus Med Hemother. 2015;42(4):247-65.

39 Robert Koch Institut (RKI). Infectious Disease Epidemiology Annual Report 2016 [accessed 2018 Sep 10]. www.rki.de/EN/ Content/infections/epidemiology/inf_dis_ Germany/yearbook.

40 Paul-Ehrlich-Institut (PEI), Funk M. Memorandum Stage 2: Arrangement of testing blood donors to prevent transmission of hepatitis E virus by blood components for transfusion and stem cell preparations for hematopoietic reconstitution. Langen: Paul Ehrlich Institute; 2019.

41 Kamp C, Blümel J, Baylis SA, BekeredjianDing I, Chudy M, Heiden M, et al. Impact of hepatitis E virus testing on the safety of blood components in Germany - results of a simulation study. Vox Sang. 2018 Nov;113(8):811-3.
42 Jarilla Fernandez M, Madrigal Sanchez M, Andujar Troncoso G, Munoz Valbuena P, Lopez-Lopez P, Frias M, et al. Should be included the universal screening for Hepatitis E virus infection in Blood donors? Results from South of Center Spain. Poster presentation at ISBT conference; 2018 Jun; Toronto.

43 Riveiro-Barciela M, Sauleda S, Quer J, Salvador F, Gregori J, Pirón M, et al. Red blood cell transfusion-transmitted acute hepatitis E in an immunocompetent subject in Europe: a case report. Transfusion. 2017 Feb;57(2): 244-7.

44 Tedder RS, Tettmar KI, Brailsford SR, Said B, Ushiro-Lumb I, Kitchen A, et al. Virology, serology, and demography of hepatitis E viremic blood donors in South East England. Transfusion. 2016 Jun;56(6 Pt 2):1529-36.

45 Grewal P, Kamili S, Motamed D. Chronic hepatitis $\mathrm{E}$ in an immunocompetent patient: a case report. Hepatology. 2014 Jan;59(1): 347-8.

46 Huzly D, Umhau M, Bettinger D, Cathomen T, Emmerich F, Hasselblatt P, et al. Transfusion-transmitted hepatitis $\mathrm{E}$ in Germany, 2013. Euro Surveill. 2014 May;19(21):20812.

47 Loyrion E, Trouve-Buisson T, Pouzol P, Larrat S, Decaens T, Payen JF. Hepatitis E Virus Infection after Platelet Transfusion in an Immunocompetent Trauma Patient. Emerg Infect Dis. 2017 Jan;23(1):146-7.

48 HEVNet [accessed 2018 Dec3] . www.rivm.nl/ en/hevnet.

49 Alfonsi V, Romanò L, Ciccaglione AR, La Rosa G, Bruni R, Zanetti A, et al.; Collaborating Group. Hepatitis E in Italy: 5 years of national epidemiological, virological and environmental surveillance, 2012 to 2016. Euro Surveill. 2018 Oct;23(41):1700517.

50 World Health Organisation (WHO) One health. September 2017 [accessed 2019 Jan 8]. https://www.who.int/features/qa/onehealth/en/.
Blood Donor Screening for Hepatitis E Virus in the European Union 